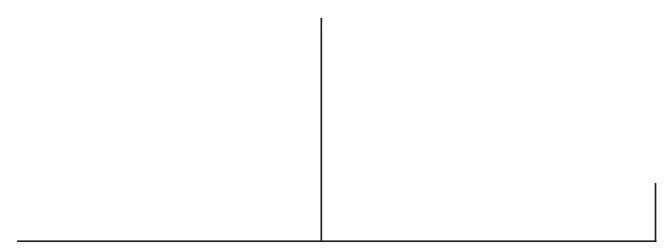

Rev. Latinoam. Psicopat. Fund., II, 2, 121-143

\title{
Erasmo: - Estranho da loucura criminal
}

\author{
Maria Fernanda Tourinho Peres
}

Neste artigo, pretendemos trazer à discussão os mecanismos de controle social que se desenvolveram em torno dos doentes mentais criminosos, sob a forma de saberes e práticas institucionalizadas. Tais saberes e práticas organizam-se segundo as estratégias médico-psiquiátrica e jurídico-penal. Através da reconstrução do caso de um paciente internado em um Hospital de Custódia e Tratamento, tentaremos demonstrar como se articula em torno da noção de periculosidade uma rede que envolve saberes, práticas, instituições e leis. Com isso podemos examinar a formação de uma nova subjetividade: o estranho sujeito da periculosidade.

Palavras-chave: Controle social, loucura criminal, hospitalização, saúde comunitária.

1. Este artigo é parte da dissertação de mestrado em Saúde Comunitária intitulada "Doença e delito: relação entre prática psiquiátrica e poder judiciário no Hospital de Custódia e Tratamento de Salvador-Ba", realizada sob orientação do Prof. Dr. Antonio Nery Filho e apresentada ao Programa de Pós-graduação em Saúde Coletiva do Instituto de Saúde Coletiva (ISC) da Universidade Federal da Bahia (UFBA) em Setembro de 1997. A realização deste trabalho foi possível graças a bolsas de estudos concedidas pelo CNPq e CAPES em momentos distintos do curso. 


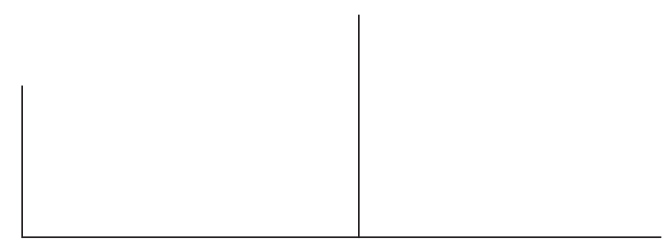

A história da loucura e, mais recentemente, a história da psiquiatria mostram a relação estabelecida entre crime e loucura, relação essa intensificada com o surgimento da criminologia e as tentativas de explicação do comportamento criminoso com base em teorias médicas pautadas em noções como hereditariedade, degeneração e influências ambientais no comportamento humano (Foucault, 1995; Castel, 1977; Carrara, 1987; Harris, 1993). O conceito de periculosidade ocupa uma posição central na articulação entre os campos médico-psiquiátrico e jurídico-penal. Utilizado pelos alienistas como argumento principal para justificar a necessidade de instituições próprias para o tratamento e reclusão dos doentes mentais no início do século XIX (Castel, 1977; Machado et al., 1978), a periculosidade passa a exercer uma papel organizador no procedimento jurídico que envolve os doentes mentais, a partir do momento em que Cesare Lombroso desenvolve a sua teoria acerca do criminoso nato e funda as diretrizes da Antropologia criminal e da Escola Positiva do Direito Penal (Carrara, 1987).

Em um texto intitulado "La evolución de la noción de ‘indivíduo peligroso' en la psiquiatría legal” (1990), Foucault nos mostra que a figura do louco-criminoso surgiu no século XIX vinculada a um tipo particular de crimes, ou seja, aqueles sem motivo e que ocorrem na esfera familiar, na maioria das vezes, aos quais poderíamos utilizar uma palavra: Estranho. É esse sentimento de estranheza, essa perplexidade, que tomaremos para começar a tecer o longo fio que envolve esses loucos-criminosos em uma rede extremamente frágil e complexa.

Em seu texto intitulado "O estranho", partindo de uma frase de Schelling que diz que "unheimlich (estranho) é o nome de tudo que deveria ter permanecido escondido ... secreto e oculto, mas veio à luz”, Freud (1987, pp. 273-318) afirma que “... esse 


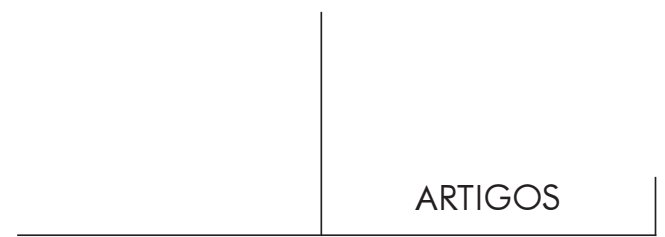

estranho não é nada novo ou alheio, porém algo que é familiar e há muito estabelecido na mente, e que somente se alienou desta através do processo da repressão" (p. 301). O Estranho apresentado por Freud, embora se refira ao que não é conhecido ou familiar, exprime ainda uma característica: o Estranho relacionase com o que é assustador, provoca medo e horror. No entanto, nem tudo que é desconhecido toma conotação de assustador e, nesse sentido, algo tem que ser acrescentado a esse desconhecido para que ele se torne Estranho. Ao desconhecido e não-familiar, acrescenta-se algo há muito conhecido, mas alienado, para que ele se torne, ou se nos apresente como Estranho: "O Estranho é aquela categoria de assustador que remete ao que é conhecido, de velho, e há muito familiar" (p. 277). Para Freud estão envolvidos nesse sentimento de estranheza “... os nossos atos de vontade suprimidos, atos que nutrem em nós a ilusão da vontade livre” (p. 295, grifo meu). Existe nesse processo de estranhamento a nossa relação com um duplo que “... converteu-se em um objeto de terror, tal como, após o colapso da religião, os deuses se transformaram em demônios". Essa sensação estranha, “... além do mais, evoca a sensação de desamparo" (Idem).

Ao longo da história da psiquiatria, podemos perceber que o louco-criminoso nos aparece como um homem representante do imponderável, ser "associal" e "selvagem", aquele que foge às leis e às normas. Esse louco-criminoso é apresentado como regido pelas paixões, pelos instintos mais cruéis e, em decorrência, seu ato aparece como incompreensível: falta um motivo racional, faltam a culpa e o remorso. Inicialmente como loucos parciais (Pinel, 1809 apud Pessoti, 1996: 83; Lanteri-Laura, 1990), em uma concepção intelectualista da loucura (Machado et al., 1978), receberão, em um momento posterior, uma nova designação a qual expande a noção da loucura para além do estado delirante: a teorização patologiza o comportamento violento e a monomania (Esquirol apud Machado et al., 1978; Carrara, 1987) cristaliza em uma entidade nosológica a associação entre loucura e crime dentro de um projeto de afirmação da estratégia alienista (Castel, 1978). Os monomaníacos matam repentinamente, sem apresentar sinais de loucura, e a eles a lógica do direito não se aplica. Mais tarde, os degenerados vêm tomar seu lugar em uma teorização que une uma concepção organicista e moral da doença mental (Morel apud Castel, 1978). Esses loucos-criminosos subvertem as leis, as normas, as relações entre os homens, as regras sociais. Seus atos são pura paixão, são "primitivos" e "selvagens", talvez possamos até dizer: são representantes do estado de natureza no homem civilizado. Esses loucos-criminosos são o nosso duplo e talvez por isso a psiquiatria e o direito criminal tenham erigido contra eles um dispositivo tão complexo, com um saber em sua base, transformando-os em doentes, criando categorias que os tornam mais humanos: a doença permite uma entrada na norma através da cura. 


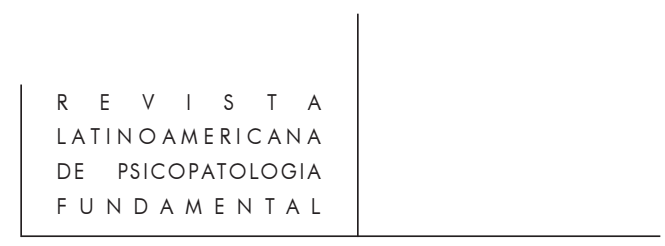

Neste artigo, pretendo trazer à discussão os mecanismos de controle social que se desenvolveram historicamente em torno dos doentes mentais criminosos, sob a forma de saberes e práticas institucionalizadas que se organizam segundo as estratégias médico-psiquiátrica e jurídico-penal. Se em um primeiro momento essas duas estratégias mostram-se discordantes e contraditórias - principalmente no que se refere à noção de livre arbítrio e responsabilidade que fundamentam a doutrina clássica do direito penal -, a história da construção do saber psiquiátrico vem nos mostrar que ambas atuam em complementaridade e conformidade. Através da reconstrução do caso de um paciente internado em um Hospital de Custódia e Tratamento, tentarei demonstrar a forma como se articula em torno da noção de periculosidade uma rede de relações que envolve saberes, práticas, instituições e leis, segundo relações de saber-poder (Foucault, 1991), as quais atuam no sentido da formação de uma nova subjetividade, o Estranho sujeito da periculosidade.

\section{A estratégia em ato}

Encaminho a esse Manicômio Judiciário devidamente escoltado o indiciado Erasmo que deverá ser submetido a exame de sanidade mental. Segue processo, bem como os autos de Incidente de Insanidade mental em apenso.

$\mathrm{Na}$ oportunidade, apresento protestos de estima e consideração.

(Ofício de encaminhamento do paciente Erasmo ao Manicômio Judiciário, pelo Juiz de Direito da comarca de Z datado de X/X/198X).

Assim se inicia o percurso de Erasmo, um doente mental que cometeu um crime e, em busca de uma loucura que o irresponsabilize penalmente, é enviado ao Manicômio Judiciário para ser submetido a um exame pericial. A verdade deve ser estabelecida, a doença deve ser comprovada, a "loucura-perigo" é chamada para dar sentido a um ato irracional: o assassinato de um membro de sua família e lesões corporais em outro. Como entender um crime em família, um crime inesperado, senão através do discurso da loucura, embasando-o por um saber, enquadrando-o nos limites da disciplina psiquiátrica? Como atuar, dentro da lógica do direito que se baseia na responsabilidade e no livre-arbítrio daqueles que cometem atos legalmente especificados como crime, se este ato foi provocado em estado de loucura? Para conferir lógica a uma intervenção penal na irresponsabilidade, a psiquiatria é chamada a estabelecer a verdade (Foucault, 1991; 1990; Castel, 1977; Carrara, 1987; Harris, 1993)

Foram, ao todo, seis internações em um período de 14 anos, no Hospital de Custódia e Tratamento (HCT). Ele chega acompanhado de um escrivão da polícia e a partir desse momento, passa a ser interno de uma instituição na qual permanecerá por longos anos, com muitas entradas e saídas, todas significativas para tentarmos 


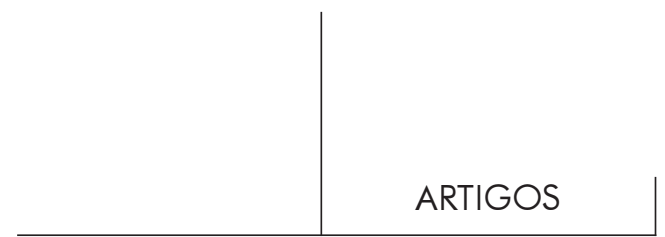

compreender a lógica que rege a estratégia da periculosidade, a qual é possibilitadora de uma nova modalidade de controle que busca, em última instância, a normatização do comportamento, um comportamento que passa a ser patologizado (Castel, 1977). O laudo de Erasmo surge dentro desta rede, trazendo o criminoso como objeto: a vida, o trabalho, a família, a personalidade, a sexualidade, as amizades, os antecedentes, os estudos, o crime contextualizado. São estes os elementos que apresentam o ser da criminalidade e não o ato criminoso. O Laudo de Sanidade Mental fecha a lacuna entre o criminoso e seu crime (Foucault, 1973; 1990;1991) com a doença reconhecida.

Um primeiro ponto que se revela significativo neste Laudo, refere-se à possibilidade de, através dele, termos uma visão de todos os elementos que compõem a estratégia da periculosidade: a justiça criminal, a autoridade policial, a família, a psiquiatria e o louco-criminoso surgem em um conjunto de discursos que mostram o Estranho da loucura em ato. Desta forma, a estratégia - que encontra na justiça criminal a sua tática e na psiquiatria o saber que a embasa - incorpora também como elementos constitutivos outras formas de controle social. A psiquiatria, como saber médico especializado, através de um corpo conceitual e teórico possui um olhar que permite ver a loucura.

$\mathrm{O}$ ato surgirá por meio do discurso familiar: o louco-criminoso começa a ser melhor delimitado. No Inquérito Policial a agitação e a agressividade são os sinais evocados de loucura, destacando-se ainda o papel da autoridade pública na estratégia psiquiátrica. Este ponto mostra-se relevante, uma vez que mesmo antes do delito a polícia é evocada como solução para a loucura-agitação de Erasmo. Neste sentido, doença e delito se confundem mesmo antes do ato, e a estratégia psiquiátrica se mantém no circuito hospital-prisão-família (Machado et al., 1978; Castel, 1977). O crime surge para o desencadeamento de uma nova tática, em um circuito que se retroalimenta pela periculosidade presumida (Castel, 1977), fundada em um ato impensado (Foucault, 1990). Assim é descrito o delito de Erasmo que, de forma brusca e sem discussão, agrediu, chutou e matou, deixando perplexos aqueles que temiam uma agressão.

$\mathrm{Na}$ versão do acusado aos peritos a fala de Erasmo mostra-se cheia de revelações; na verdade, ela poderia até mesmo ser considerada como um resumo de todo o processo que ele até agora vem sofrendo: a doença, o delito, sua história de vida como parte do ocorrido e a irresponsabilidade surgem em um discurso que extrapola a mera descrição do ato praticado - é o criminoso e não o crime que surge em sua versão quase que numa reprodução em palavra da estratégia na qual está inserido. Ele a transforma em um discurso, que já não é só seu, mas produzido pela rede na qual se encontra (Foucault, 1971): é um discurso formado pelo que ele nos mostra. Foi um acidente, ele diz e explica, porque estava transtornado pelas injustiças sociais, porque não conseguia trabalho, porque não era aceito em sua 


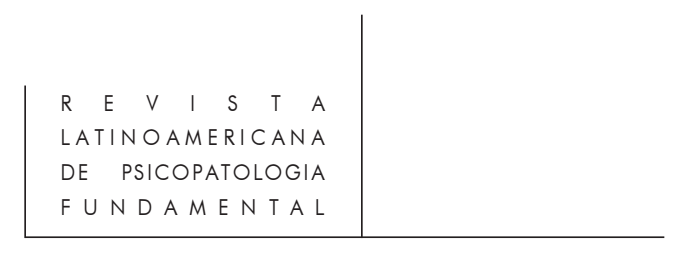

comunidade, porque sua história deixou nele marcas de uma personalidade anulada e graves transtornos emocionais: "eu estava fora de si"... "esta pessoa não é responsável pelos seus atos". A periculosidade e a irresponsabilidade entram em seu discurso, no entanto, nesse momento ele ainda diz: "Eu não sou maluco e quero provar na justiça que tudo foi um acidente" (Laudo de Sanidade Mental). Em um momento posterior, essa afirmação vai ser reformulada e a periculosidade, a irresponsabilidade e a doença vão ser por ele incorporadas como uma cristalização e um dado quase inquestionáveis.

Depois do delito e do Inquérito Policial, surge no laudo a doença, na seção a ela destinada: a anamnese visa reconhecer a loucura, destacar os pontos de sua história que sejam indicativos de uma doença que virá irresponsabilizá-lo, tornando impossível que ele prove ter sido um acidente, retirando dele a possibilidade de um julgamento, marcando o perigo que ele representa (Foucault, 1990; Castel, 1977). Dentro desse quadro, a doença o absolve sem que ele possa ser, na realidade, absolvido: a absolvição pela loucura é no mínimo curiosa, uma vez que se nega a si própria.

A doença de Erasmo surge em uma reconstrução de sua vida compondo o "retrato" de sua personalidade. Passa-se então à descrição de suas diversas internações em hospitais psiquiátricos, e estas se mostram relevantes por definirem a imagem do doente-perigoso. A história psiquiátrica é marcada pela agressividade ou, talvez, esses tenham sido os relatos privilegiados para a composição de seu laudo: a passagem por hospitais psiquiátricos, mais do que confirmar a doença, confirma uma doença perigosa, cristalizada através de uma agressividade contra a sua família. Já no HCT, no exame psíquico apresentado no laudo, surgem elementos que possibilitam o diagnóstico: "diversas alterações da senso-percepção" que surgiram durante a entrevista. No entanto, destaque é dado a uma requisição entregue por ele aos peritos:

Requeiro através desta, exame laboratorial médico para constatar presença de equipamento médico-científico de gênero microfilmadora, microfotográfico ou utilização de infravermelho, ultravioleta, aparelhos usados em serviços médicos a que suspeito e tenho certeza de estar sendo usados em meu corpo humano, por médicos e homens de ciência inescrupulosos, que o utilizam para fins de lucro e terrorismo. Peço também ao serviço social a constatar parentesco sanguíneo com os antecedentes da vítima ao artigo acima, item primeiro. Peço também ao departamento de polícia desta unidade verificar responsabilidades paternais da família hora queixosa. Requeiro também através do corpo jurídico desta entidade, verificar laços matrimoniais durante a vida pregressa e legitimidade paterna de filhos adquiridos com A, matrimônio adquirido usando os métodos acima especificados ao qual recebera anulação e exige processo.

Atenciosamente. Ass. Ilegível. 


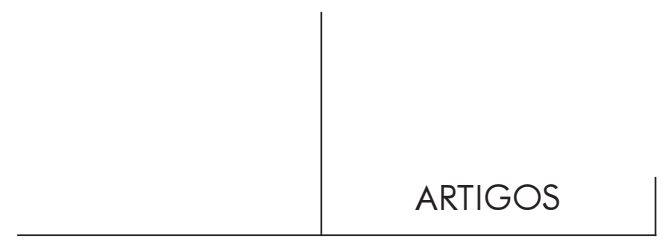

Em um requerimento entregue por escrito, chaves para o seu diagnóstico: falas absurdas, um encadeamento de idéias incoerente, uma posição de vítima de perseguição e invasão de seu corpo. No entanto, podemos também perceber a reformulação de seu percurso: ele traz a medicina que invade seu corpo, ou talvez possamos dizer, sua vida; a família queixosa contra a qual o seu ato foi dirigido, mobilizando a estratégia em que está inserido; o seu casamento que não deu certo e tem relação com o início de sua doença. Uma história que ainda não acabou, mas que terá um fim: o que vai ser? Ainda no exame psíquico, os peritos destacam a recusa da doença, o pedido de Erasmo por um julgamento: a inimputabilidade é questionada pelo doente, assim como a absolvição pela loucura.

Estes são os elementos trazidos no laudo: o Inquérito Policial presente nos autos processuais, entrevistas e observações durante o internamento. Através deste exame que busca a doença, sua história foi evocada, sua vida entrou para a conformação do criminoso em julgamento (Foucault, 1990, 1991). Negando a doença até então, resistindo a enquadrar o seu discurso no registro da loucura deu, em alguns momentos, pistas fundamentais. A partir delas, chega-se à conclusão:

... concluímos ser o presente periciando portador de uma psicose endógena, Esquizofrenia, que se caracteriza pela apresentação de sintomas psicológicos específicos e que, em geral, ocasiona completa desorganização da personalidade que se evidencia no curso da vida de Erasmo há 7 anos, nas diversas internações realizadas..., e no exame psíquico atual... (Laudo de Sanidade Mental: conclusões).

Através do laudo, a verdade do ato, a doença confirmada, a lógica para o delito. Através das respostas dos peritos aos quesitos formulados pelo Ministério Público, entrará definitivamente na estratégia da periculosidade através da afirmação de sua loucura perigosa e de sua incapacidade. No entanto, já na conclusão do laudo dizem os peritos:

Ressaltamos que após o uso de medicação específica o presente interno remitiu os sintomas psicopatológicos que atuaram como fatores psicogênicos à época do delito (junho de 198X).

A remissão do quadro, no entanto, não será levada em consideração e ele permanecerá internado por três anos e dez meses, seguindo-se à sua desinternação mais cinco retornos ao HCT. O Laudo de Sanidade Mental, então, através do reconhecimento da loucura, possibilita a entrada do doente mental no campo das sanções penais, e o médico, com o seu saber autorizado, desempenha um papel fundamental neste processo (Foucault, 1990; Castel, 1977).

Um ponto que vale a pena ressaltar, refere-se à temporalidade que parece acompanhar a lógica da estratégia da periculosidade. Apenas nove dias após o encaminhamento do laudo ao Juiz de sua comarca, a Medida de Segurança provisória foi decretada: Erasmo deverá então permanecer no HCT até que o seu processo 


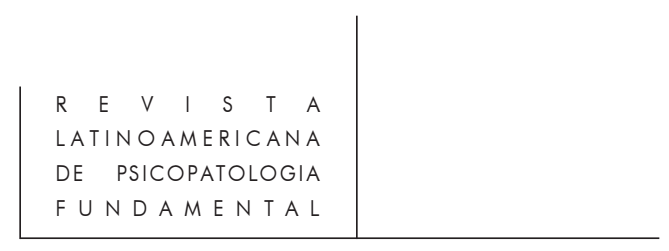

seja apreciado pelo Juiz, mantendo-se, a maior parte do tempo compensado psiquiatricamente, com apenas dois "surtos" identificados, ambos durando cerca de um mês. Veremos a rapidez desse procedimento jurídico se repetir apenas para as re-internações: inúmeros ofícios serão enviados ao Juiz de Direito; mais de um Habeas Corpus será impetrado em seu favor, mas a situação processual custará a ser regularizada nesta sua primeira passagem pelo HCT. A interferência judiciária na prática psiquiátrica começa então a ser percebida não mais através da amplitude dos dois campos de conhecimento/controle, mas sim através da cotidianidade do HCT. A decretação dessa Medida de Segurança provisória traz a ambigüidade da instituição (Dantas Jr., 1987: 103-106): a "internação" para tratamento de um paciente que está com o quadro psicopatológico em remissão. Custódia ou tratamento? A permanência de Erasmo no HCT por um período de 3 anos e 10 meses com reinternações sucessivas. Absolvição?

Em uma visita da assistente social do HCT à cidade de Erasmo, para contato com a família e com o juiz no sentido de regularizar a sua situação judicial, ela afirma: "O caso desse paciente é bastante conhecido pelos funcionários do Fórum, inclusive pelo Juiz, que se mostraram um pouco inseguros sobre a sua recuperação" ${ }^{2}$. A insegurança quanto a sua recuperação, jogará, a partir de agora, um papel central nesta estratégia, assim como a sua relação com seus familiares.

Após dois anos de internação a direção do HCT escreve um relatório, na tentativa de regularizar a sua situação visando, inclusive, uma provável alta:

Não há qualquer registro de ato de indisciplina no prontuário do interno, sempre bem comportado, colaborador e bem relacionado com os colegas e funcionários. Segundo as informações do médico assistente é viável o retorno do paciente ao convívio sócio-familiar. Sendo assim, somos, também, favoráveis ao reingresso do mesmo ao seio da sociedade.

Neste sentido, ao relatório acima adicionou-se um primeiro Habeas Corpus impetrado a seu favor, o qual, julgado em agosto do mesmo ano, foi indeferido por unanimidade, alegando-se a inatualidade do retardamento do processo, a inexistência de coação, recomendando-se a prolatação imediata da sentença.

A sentença recomendada não é prolatada, e tentativas são feitas por meio de ofício ao Juiz de Direito encarregado e de dois novos Habeas Corpus que serão impetrados. A Assessoria Jurídica do Departamento de Assuntos Penais (DAP) encaminha um ofício ao Juiz encarregado de julgar o processo, baseando-se nas recomendações feitas pelo Tribunal de Justiça, no sentido da prolatação imediata da sentença, acrescentando ainda que "trata-se de um paciente completamente

2. Fonte: Relatório da viagem para contato com as famílias de pacientes do interior do Estado Serviço Social; Hospital de Custódia e Tratamento. 


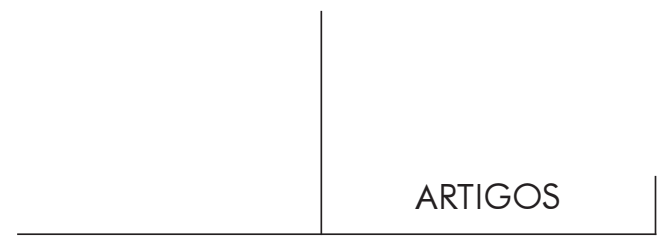

lúcido, possuindo condições de sobrevivência fora dos muros hospitalares". Concluem com a seguinte declaração: “...o paciente está internado há quase três anos e, caso fosse decretada a Medida de Segurança em seu limite máximo, esta já começaria vencida...". Começamos então a perceber a ambigüidade presente no procedimento jurídico em torno da loucura, o qual absolve o "indiciado" e o engloba em uma rede que, com seus artifícios, o mantêm internado. Este ponto tornar-se-á mais claro à medida que acompanharmos o percurso de Erasmo e, neste sentido, tomaremos também os dois novos Habeas Corpus impetrados e indeferidos, cujo espaço de tempo entre eles (seis meses) foi marcado por um "silêncio jurídico" que muito nos diz.

Os três Habeas Corpus trazem elementos importantes para serem discutidos, uma vez que utilizam como base de sua argumentação a rede jurídica estabelecida para dar conta desta loucura-criminosa: a Medida de Segurança, a inimputabilidade, a irresponsabilidade e a conseqüente absolvição da loucura. A Medida de Segurança é juridicamente formulada como uma medida preventiva que visa o futuro, também diferenciando-se da pena por não ter um caráter aflitivo. Mais do que isto, ela não é determinada com base no crime, mas sim na periculosidade do doente, dizem os juristas (Oliveira e Silva, 1942; Hungria \& Fragoso, 1978; Jesus, 1988; Noronha, 1990; Delmanto, 1991; Cohen, 1996). Soma-se à Medida de Segurança, a absolvição, por não ser o doente considerado responsável pelo ato: a doença é causa excludente de culpabilidade e os loucos-criminosos são considerados irresponsáveis. É a doença a causa do crime e, por isso, o doente irresponsável não pode ser punido, devendo ser tratado e, para isso, existem essas Medidas de Segurança. Desta forma, foi possível ao Direito atuar sobre a loucura com uma nova lógica (Castel, 1977; Foucault, 1990): a responsabilidade e o livre-arbítrio estão ausentes desta.

São estes os elementos trazidos nos três Habeas Corpus como tentativa de desinternação. No segundo, encontramos o argumento da periculosidade: Erasmo não oferece mais perigo à sociedade. Em todos, a inimputabilidade está posta em questão, uma vez que a Medida de Segurança parece estar funcionando como uma pena: perdeu seu caráter preventivo, recuperador. A medida de segurança de Erasmo surge então como aflitiva, punitiva e retributiva.

Um ponto ainda que deve ser considerado, é o indeferimento dos Habeas Corpus: todos foram considerados improcedentes. Infelizmente não encontramos no prontuário o julgamento da apreciação dos últimos, no entanto, se considerarmos o primeiro Habeas Corpus impetrado em favor de Erasmo, e indeferido por não ter sido considerada atual a coação alegada, podemos perceber que o indeferimento entra na composição da estratégia, mantendo o paciente internado com base em argumentos jurídicos. Erasmo estava, quando do primeiro Habeas Corpus, internado há dois anos sem que houvesse sido sequer enviada a Guia de Internação. No entanto, a coação não era atual; mais do que isto, ela deixou de existir. $\mathrm{O}$ 


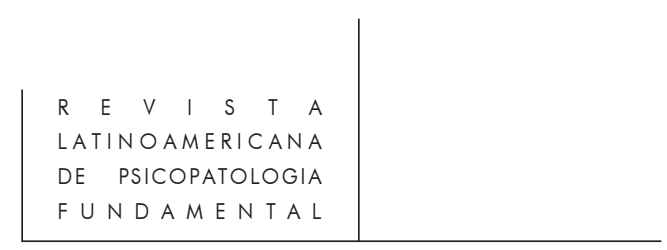

indeferimento parece trazer o refinamento de artifícios que mantêm a coação sem que ela exista. Desta forma também parece atuar o juiz que, num retardamento do processo, afirma estarem os "autos conclusos e a instrução concluída", sem no entanto decretar a sentença. Assim se mostra para nós a temporalidade na estratégia: ela parece trazer uma intencionalidade, a qual pode ser percebida concretamente em seu efeito: prolonga consideravelmente o tempo de internação, mantêm sob controle o Estranho.

A regularização do processo vai se mostrar como uma conclusão em aberto. Após a realização do Laudo de Cessação de Periculosidade a sentença será prolatada determinando a sua desinternação. Na "loucura-perigosa", no entanto, a desinternação é provisória; segue-se ao período de internação uma fase condicional de liberdade, podendo a situação anterior ser restabelecida. Uma absolvição que interna; uma Medida de Segurança que se diz preventiva e terapêutica, mas que pune; uma liberdade condicional. São estes os elementos que marcam a atuação do Direito Penal na loucura, uma loucura que é, por si, ameaça. A prevenção se estende no tempo em uma Medida de Segurança que vai além do Manicômio Judiciário: na loucuraperigo, a atuação jurídica se dá além dos muros e do período de internação. Isto se mostra evidente no Salvo Conduto, documento que acompanha a Carta de Desinternação e que estabelece o "correto" modo de viver do louco-perigoso em 12 regras bem definidas. A amplitude do salvo conduto parece servir a uma estratégia que volta-se ao controle de uma ameaça permanente (Castel, 1977). Manter bom comportamento, buscar ocupação, ter um bom relacionamento com familiares e estranhos, não freqüentar festas, lugares de jogos, casas de prostituição, bailes carnavalescos, não beber: o que resta a este Estranho além de uma cristalização de sua posição de ameaça freqüente?

Vinte e dois dias após a sua desinternação, Erasmo volta ao Manicômio Judiciário para ser re-internado, trazido por um irmão e um policial. Com eles, um ofício do Delegado encaminhado ao Juiz de Direito da Vara de Execuções Penais. As reinternações surgem então nesta estratégia, utilizando-se dos amplos limites de atuação por ela possibilitados: após 3 anos e 10 meses de internação, com um quadro psiquiátrico "compensado" durante quase todo o período, Erasmo sai de alta, e com base no salvo conduto e em nome de uma prevenção que marca a atuação jurídica na loucura -, volta ao Manicômio Judiciário em menos de um mês. É a estratégia em ato, mobilizada por uma loucura selvagem e furiosa que vemos se desenrolar; é a forma de reconhecer este Estranho da "loucura-perigosa" que, preso em limites que definem a área de atuação do Direito e da Psiquiatria, entra em um jogo no qual participam também a polícia e a família. Vejamos como se deu a sua reinternação, cujos motivos são dados pelo seu irmão: as más companhias e a bebida alcoólica caracterizam a quebra do salvo conduto e se constituem no mobilizador de seu retorno, cujo caráter de tratamento não aparece quando vemos o seu exame 


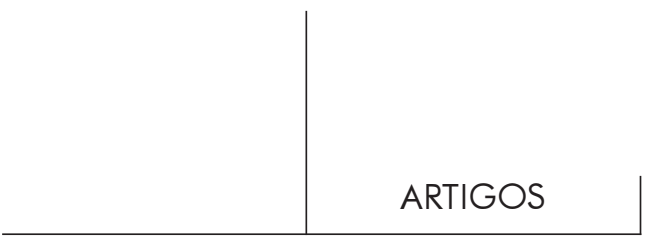

psíquico: "Paciente veio com vestes adequadas. Asseio corporal satisfatório. Lúcido, orientado, pragmático. Não foram detectados distúrbios alucinatórios delirantes. Ansioso, um tanto irritado. Refere que passou menos de 48 horas fora da cadeia, logo foi preso sem motivo aparente". Diz ainda Erasmo na sua re-internação: “... eu fiquei preso, almoçando uma vez por dia... a prisão não era legal, teria que satisfazer a família... o pessoal teme a mim”. (grifos meus)

Por ocasião do internamento, a Diretoria do Manicômio Judiciário encaminha ofícios para o Juiz de Direito da Vara de Execuções Penais e para o delegado e, em ambos destaca a família como sendo a mobilizadora de sua re-internação, e a periculosidade da loucura se situa na base desse procedimento, justificando não mais a internação primeira, mas um retorno ao manicômio. No entanto, um momento inicial é apresentado: Erasmo fica na cadeia, evidenciando-se mais uma vez que essa instituição de controle permanece entre nós como um lugar da loucura. Este ponto torna-se relevante quando vemos o que mobilizou esta re-internação: as más companhias e um provável uso de bebidas alcoólicas, não configurando um crime. No entanto, a "loucura-perigosa" parece justificar a prisão. Mais significativo ainda mostra-se a ausência da doença, caracterizando-se neste momento um internamento "contra-indicado" em termos médicos.

Esta segunda internação foi curta, durando apenas 3 meses. Erasmo, então, saiu de alta por determinação do Juiz de Direito da Vara de Execuções Penais permanecendo 2 meses e 23 dias em liberdade, quando foi novamente re-internado, desta vez trazendo um ofício do Juiz de Direito da comarca de Z e uma Certidão do Delegado. Vejamos os termos desta última:

... promovesse a remoção do toxicômano e homicida Erasmo..., isto o determinando como medida de precaução... Em se tratando de um elemento cuja_periculosidade alcança as raias do absurdo, determinei a sua detenção, onde se encontra até o presente momento.

Desta forma, fica claro que o mobilizador maior das reinternações, neste caso, é o perigo que Erasmo representa para a sociedade, com sua periculosidade que "alcança as raias do absurdo". Um ponto importante a ser destacado é que aos poucos vai se conformando um percurso que nos mostra que é pelo que esta estratégia apresenta de "positivo" - no sentido de ser formulado como um procedimento que protege o doente contra a injustiça da punição por um ato em estado de doença - que a ela é permitido uma gama de artifícios que envolvem o doente em uma rede que nos apresenta interminável. As reinternações de Erasmo são múltiplas e por motivos diversos, estando presente em todas a ameaça que esta loucura representa. É por ela, e para evitar novos crimes, que este procedimento é formulado em termos de prevenção. A atuação jurídica na loucura é uma atuação na órbita da prevenção criminal e, por isso, deve preceder o crime futuro. É esta a 


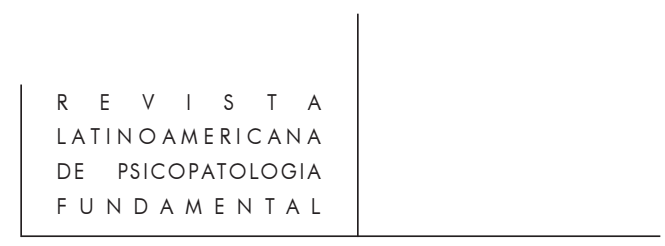

lógica das reinternações, que dispersam o seu caráter terapêutico. É isto que o percurso de Erasmo vem mostrar.

"Uma prisão sem delito", é assim que aparece este retorno ao HCT: sem lógica para o paciente. A contradição deste procedimento que se utiliza do argumento da doença e de um tratamento que se estende no tempo, aparece sob a forma de uma questão: "como é que eu vou saber porque fui preso?" A resposta para esta pergunta se encontra em um tempo futuro, em um novo crime que pode ou não acontecer por sua periculosidade. Um ponto interessante, no que se refere às reinternações, surge em entrevista, em uma fala de Erasmo após 14 anos de sua primeira internação. A comunidade - aqui materializada em sua cidade da qual ele sente saudade, e à qual ele não pode mais voltar - parece exercer um papel importante na determinação de seu retorno ao HCT, destacando-se como elemento significativo o medo diante da loucura: "a loucura causa medo"... "eles pensam que a gente vai matar"... "eu cheguei a causar uma espécie de pavor". O crime primeiro parece ter marcado Erasmo, e ele causa pavor, a polícia fica de prontidão; autoridade policial é então trazida, como parte deste retorno, assim como a "discriminação" pela loucura-violência: o "maluco" então, tem seu lugar "na cadeia e na esbórnia". As repercussões em sua vida aparecem, e a impossibilidade da retomada de um passado anterior ao crime mostra-se através da necessidade da busca: Erasmo diz ter que "recomeçar a reviver". Começar mais uma vez uma vida que foi interrompida, é o que essas palavras parecem dizer. Na estratégia da periculosidade, a loucuracriminosa estabelece um marco, entre um passado e um futuro que não mais se encontram.

O estatuto de Estranho da loucura em ato, aparece ainda na fala de Erasmo: "ele tava fugindo dele próprio, com medo dele". A loucura-criminosa parece desencadear uma estratégia que se mostra interminável em sua duração, cheia de possibilidade de contenção, com múltiplas táticas para a reclusão. A esta prática soma-se um discurso jurídico que a diz preventiva, terapêutica e pedagógica. O medo de nós mesmos, daquilo que de mais profundo existe em cada um parece exercer um papel importante nesta multiplicidade de táticas e infindável estratégia. O louco-criminoso, este Estranho que não reconhecemos, que nos assusta e nos questiona, deve ser contido. A doença pede um discurso que absolva, trate e eduque. A prática, pede um controle indeterminado. Este paradoxo prática-discurso mostrase então como um elemento importante de manutenção do que está; permite a quem sustenta esta estratégia em discurso, o benefício do locutor (Foucault, 1988): os textos jurídicos parecem trazer esta questão. Em uma rede que se multiplica a doença parece, como disse um dos médicos, ocupar um lugar secundário.

Desta forma, na ficha desta nova internação, mais uma vez o tratamento é posto em questão, cristalizando uma nebulosidade em torno da absolvição destes loucos-criminosos. Diz Erasmo: “... (é) por causa dos antecedentes... já aconteceu 


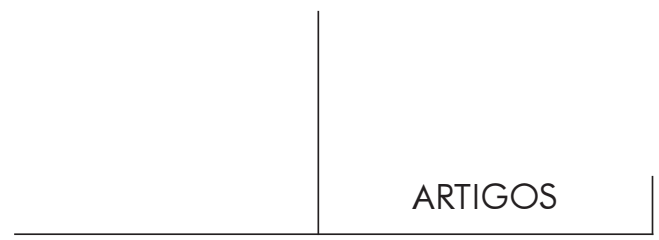

uma vez, acham que vai acontecer sempre... infelizmente eu não vou ter mais sossego”, “... supostamente teria a intenção de matar minha yyy... quem já fez uma vez fica marcado porque já não tem mais condições de viver lá fora” (grifos meus). Assim, começa a se mostrar "o que vai ser", e a afirmação de Erasmo em sua primeira internação ("eu não quero saber o que foi, mas o que vai ser") parece ser respondida; o exame psíquico mais uma vez põe em suspenso o caráter "terapêutico" desta internação, onde o sintoma parece não marcar esta atuação na loucura-criminosa; a doença parece não exercer, neste "tratamento", um papel privilegiado, mas sim o delito que toma o seu lugar e confunde-se com ela. Preso nas redes de uma estratégia que possui uma possibilidade de atuação fantástica, Erasmo mantém-se nesse jogo de entradas e saídas possibilitadas por um saber psiquiátrico que viu nele a "verdade da loucura", e por um corpo conceitual do direito que definem a inimputabilidade, a Medida de Segurança como forma de atuação, e a periculosidade que estabelece o contato entre os dois campos. É interessante o registro de seu médico-assistente feita no dia da internação: os procedimentos formadores de discursividade (Foucault, 1971) mostram-se nesta passagem, na qual o que Erasmo diz é tomado como sinal de sua doença, abstraindose o percurso que vem se desenvolvendo. À afirmação de Erasmo de que "todos" estão contra ele e ao seu pedido para não interpretar o que diz como psicose, o seu médico enquadra em termos psicopatológicos, coloca o seu discurso dentro de um registro técnico e conceitual nos limites da disciplina psiquiátrica: delírio de referência e desconfiança entram para configurar um quadro de paranóia. No registro seguinte, o médico de Erasmo afirma: "Aparentemente bem. - 'Não tô ótimo, mas tô bem. As perseguições sumiram...'. Trabalhando controle das emoções (às vezes com raptus frente a família) daí o seu reinternamento". O seu retorno é explicado pelo seu comportamento agressivo, por uma loucura que é toda violência, confirmando internamente e através do saber médico-psiquiátrico a argumentação utilizada para o seu re-internamento, ao assumir a agressividade de Erasmo como resultante de emoções descontroladas.

Esta terceira internação durou um ano e quatro meses. Em outubro de 198X+4 a Assessoria Jurídica do Patronato de Presos e Egressos encaminhou ao Juiz de Direito da Vara de Execuções Penais uma solicitação de desinternação para Erasmo, argumentando que “...entendemos que não houve qualquer violação dos enunciados artigos do Código de Processo Penal visto faltar, no caso em questão, os elementos essenciais à configuração da tipicidade penal”.

Em novembro o Juiz solicita que seja realizado o Laudo de Cessação de Periculosidade. Concluem os peritos estar Erasmo em "perfeitas condições atuais de retornar ao seu convívio familiar, mesmo porque, nas presentes condições, já se torna nociva a sua internação em ambiente psiquiátrico" (grifos meus), apresentando para fundamentação dessa conclusão um diálogo que tiveram com o 


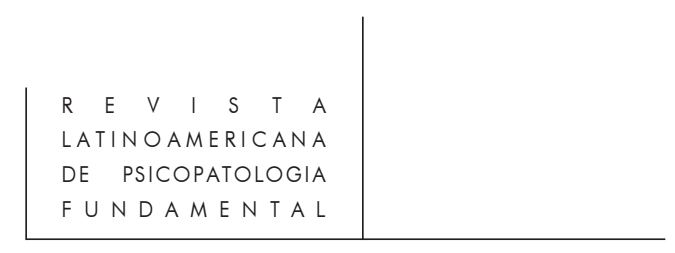

paciente, no qual alguns pontos mostraram-se significativos, sendo um deles a forma como fala de si: não mais apresenta a rebeldia que o caracterizou nessa passagem pelo Manicômio. No lugar de vítima traz um discurso que se enquadra à estratégia da periculosidade: pessoas como ele não merecem confiança, e é esta a mensagem que a noção de periculosidade traz pelo risco que representa a loucura. Soma-se ainda a esta afirmação de Erasmo mais uma: ele sabe o que o espera se voltar à conduta do passado. No procedimento jurídico da loucura o futuro é também englobado e se torna previsível para Erasmo, neste momento de sua história, ao menos que ele siga outros caminhos e, neste novo período que ora se apresenta, ele parece ter tomado outro caminho, este não longe dos tóxicos ou do álcool, mas longe de sua cidade e de sua família.

Erasmo sai de alta através de Alvará de Soltura e, desta vez, ficará em liberdade por três anos e sete meses: usando drogas e bebendo, sem emprego fixo e sem casa, porém, longe de sua cidade. Permanece fora do Manicômio apesar de "quebrar" o Salvo Conduto em pelo menos quatro itens. À sua cidade, retornou apenas para providenciar novos documentos, dizendo ter sido preso no mesmo dia, e encaminhado ao Manicômio Judiciário três meses após a prisão, tempo em que permaneceu na Cadeia Pública. Vejamos como ele reconstrói este percurso, o qual foi transformado por ele em discurso na entrevista, no qual ganham evidência alguns aspectos da sua trajetória, incluindo sua permanência em liberdade, durante três anos e sete meses. Sem emprego, drogado, carente do apoio familiar, impossibilitado de retornar à sua cidade, sem casa, com fome, interditado pela justiça e "andando pelos hospitais psiquiátricos como doente mentiroso", Erasmo identifica uma série de impossibilidades. No entanto, em que pese a importância deste relato enquanto experiência de quem a viveu, o que se mostra significativo é, mais uma vez, o perigo representado e o crime em seu "estado de doença": em um percurso que se dá em torno de uma loucura violenta, o crime cristaliza-se na doença, e eles se confundem. Por um crime primeiro, ele diz: "pensavam que eu era instintivamente maligno", "não acreditavam no que eu dizia". Um ato passado, marca um risco futuro, e a ameaça que ele representa toma forma de uma nova denúncia, e assim ele retorna mais uma vez ao HCT.

Outro aspecto importante, consiste em que tendo passado mais de um ano de sua saída do Manicômio Judiciário, a Medida de Segurança já estava extinta, Erasmo não estava mais em liberdade condicional quando voltou a Z; ele estava livre. O Salvo Conduto já não possibilitava a solicitação de uma nova internação e, talvez por isso, tenha sido enquadrado em um novo delito: ele era agora acusado de crime de ameaça, tendo sido encaminhado ao Manicômio Judiciário para realização de um novo Laudo de Sanidade Mental, e, posteriormente, submetido a uma nova Medida de Segurança. Retornemos ao início... Com ofício encaminhado 


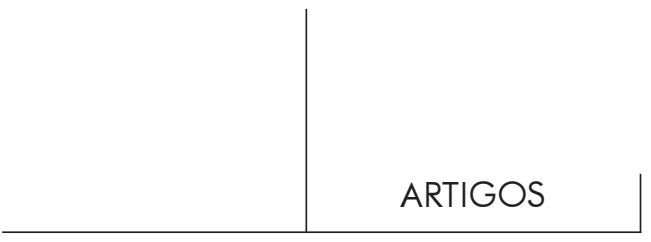

ao Diretor do Manicômio Judiciário Erasmo está mais uma vez de volta. Vejamos a sua quarta ficha de admissão e o que ele diz na História Criminal:

Eu cheguei em $\mathrm{Z}$ para pegar uns documentos, a moça do Fórum me mandou ir no outro dia; quando foi 8 horas da noite a polícia me prendeu, sem motivo nenhum.

Em seu exame psíquico, mais uma vez vemo-nos diante de um tratamento questionado:

Comparece à entrevista de internamento acompanhado de policial. Traja-se convenientemente. Em lucidez de consciência, orientado globalmente, calmo. "Não tem nada me incomodando, o juizo tá bom, não tô vendo nada, nem bicho". No momento não percebemos distúrbios psicóticos. Humor normal. Postura algo irreverente.

Assim permanecerá Erasmo durante toda a internação, queixando-se apenas de ansiedade e insônia; não percebemos em seu prontuário médico um registro sequer que identificasse um surto psicótico em desenvolvimento.

Os peritos são designados para a realização do novo laudo um mês após sua re-internação, o qual vem reafirmar uma doença já conhecida que mais uma vez atuou como mobilizadora do crime: quando Erasmo ameaçou, ele não sabia o que estava fazendo, estava em um estado que o incapacitava (Código Penal, art. 26). É importante destacar as circunstâncias da sua detenção, a forma como é descrita por Erasmo. Depois de ter passado três anos em liberdade ele volta à sua cidade e, “... sem motivo nenhum..." é preso. Talvez este seja o momento mais representativo em todo seu percurso, desta rede que o envolve e da qual ele faz parte.

Alguns elementos, no entanto, merecem ser discutidos. Inicialmente, podemos perceber que o discurso trazido neste exame, no que se refere à denúncia e ao termo de declaração, parece - além de reproduzir a estratégia, possibilitando o novo internamento - ser produzido pela lógica que a rege. Desta forma, mais uma vez os elementos formadores de discursividade mostram-se evidentes: a periculosidade, elemento central deste procedimento jurídico na loucura, é também a justificativa para este retorno. Erasmo ameaçou e, por ser um "elemento por demais perigoso" deve ser contido e, neste sentido, o crime primeiro reaparece como uma marca que cristaliza este perigo representado. Também naquilo que diz a assistente social da prefeitura, o risco que Erasmo representa surge, conformando o discurso da periculosidade: Erasmo causa intranqüilidade à população da cidade e à sua família e, além disso, ele a ameaçou de morte. A estratégia conforma o discurso que é produzido no sentido de promover a sua perpetuação: o discurso faz parte da estratégia, assim como os conceitos que a sustentam e as táticas que a põem em movimento.

Um outro ponto que se mostra significativo, é a forma como o seu discurso é tomado pelo perito que o examina: diante da revolta e descrença na justiça e de 


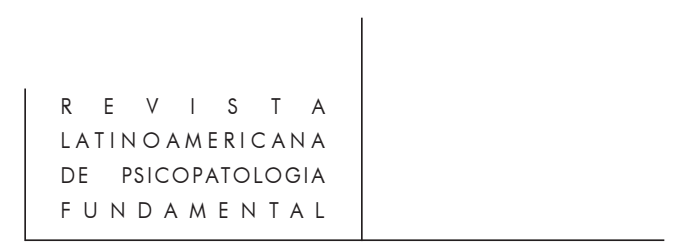

se achar vítima de perseguição, os limites da disciplina psiquiátrica, a oposição loucura-razão e a vontade de verdade (Foucault, 1971) se mostram no exame psíquico. O perito, que busca reafirmar uma doença já conhecida, enquadra o discurso do paciente em um rótulo, em uma afirmação que traz o diagnóstico: Erasmo estava persecutório, e a medicação o fez mais abordável e participativo. A doença reconhecida possibilita, neste momento, o benefício do locutor (Foucault, 1988): é ela a causa de sua angústia, de seu sofrimento e de sentir-se perseguido. A rede que o envolve é excluída, assim como o médico que dela participa. Ainda neste sentido, as repercussões desta estratégia em sua vida também são incorporadas em seu quadro psiquiátrico, se "encaixam no prognóstico da doença". Mais uma vez, a sua loucura tornou sua vida sem objetivo, tirou dele a sua motivação, resultando em hospitalizações freqüentes e gerando a desadaptação familiar.

Somente dois anos depois de re-internado, foi prolatada a nova sentença, que decretava uma nova Medida de Segurança por dois anos, considerando-se Erasmo absolvido pelo crime de ameaça. A alta desta quarta internação ocorrerá após a realização de um novo Laudo de Cessação de Periculosidade.

Esse novo Laudo, traz um elemento que pensamos ser importante destacar,, o qual vem no lugar de uma fala de Erasmo: "Conversa sobre sua situação, sua perspectiva de saída, faz uma autocrítica do que vem lhe acontecendo e a necessidade e disponibilidade em modificar seu roteiro de vida...”. Esta afirmação, destacada pelos peritos como um sinal de sua recuperação, nos confronta mais uma vez com o benefício do locutor. Sentimos através dela uma responsabilização do irresponsável, ou seja, o que vem lhe acontecendo nestes longos anos de entradas e saídas do HCT é identificado como sendo um problema dele, o que justifica o termo utilizado - autocrítica - e a necessária modificação de seu roteiro de vida. O médico, desta forma, abstrai o seu papel de reprodutor da estratégia, assim como o papel da rede judicial que envolve a sua prática. Percebemos, ainda, as conseqüências deste percurso em sua vida: Erasmo parece vir aos poucos se conformando como um sujeito vitimado-vitimante que oferece perigo e não consegue mais trabalho, não pode mais voltar à sua cidade, não conta mais com sua família.

À alta, segue-se uma nova internação 25 dias depois, autorizada pelo Juiz de Z para "definir a sua situação psíquica" . Esta nova internação dura 5 meses, durante os quais Erasmo permanece "lúcido, orientado globalmente", "sem distúrbios psíquicos evidentes", "bem psiquicamente", "compensado"4. A alta se deu em novembro, à qual seguiu-se uma nova internação em junho do ano seguinte,

3. Ofício encaminhado ao Hospital de Custódia e Tratamento pelo Juiz de Direito da comarca de Z, junho, 199Y+2.

4. Evolução Médica - Prontuário: junho; agosto; setembro e novembro de 199Y+2. 


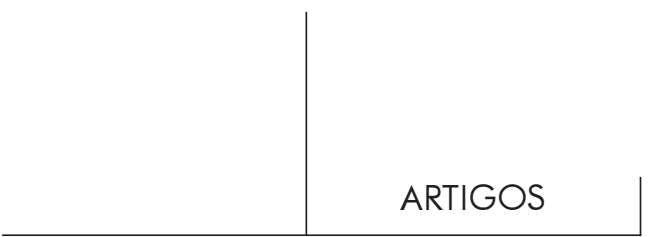

internação que corresponde ao nosso período em campo. Deste novo retorno, tomaremos inicialmente a sua ficha de admissão em totalidade:

História Criminal: "Vide informações anteriores".

História da Doença Atual: "Paciente saiu do HCT em novembro de 199Y+2 com Carta de Desinternação. Durante um período usou a medicação prescrita no HCT. Internou no hospital $\mathrm{H}$ porque teve uma discussão com o irmão. No hospital $\mathrm{H}$ passou a usar ${ }^{\circledR}$ de 5 em 5 dias o que o deixou impregnado (ficou 15 dias no hospital $\mathrm{H}$ ). Paciente volta para internar no HCT porque não tem onde morar, não está tomando remédios, está dormindo pelas ruas e não alimenta-se adequadamente.

Exame Psíquico: Paciente calmo, abordável, pragmático, parcialmente orientado. Sem sintomas psiquiátricos proeminentes (somente sinais de impregnação neuroléptica). O que está estimulando o internamento é a situação social do paciente (Não ter onde morar etc.) Paciente em péssimas condições de higiene. (grifos meus)

À ficha admissional soma-se ainda a prescrição feita pelo médico plantonista por hora da internação:

... paciente com situação social difícil, não tendo onde morar, insistindo em se internar. No momento, não apresenta sintomas psicóticos iminentes: calmo, abordável, orientado alopsiquicamente, pragmático. Internamento autorizado pela direção. (grifos meus)

O que esta nova ficha de admissão mostra é um Erasmo marcado por um passado de violência, e por um futuro de ameaça. Na história criminal, as "informações anteriores" dizem o que ele fez, qual crime cometeu. No entanto, dizem também o seu percurso, a sua história que é agora marcada pelo perigo que ele representa. Erasmo diz que não pode mais voltar à sua cidade, que causa pavor às pessoas e, diante disto, vemos uma vida marcada pela impossibilidade: ele não tem onde morar, não toma remédios, dorme nas ruas e não se alimenta; pede então para voltar ao HCT. As reinternações marcam o seu percurso e aparecem agora como única possibilidade: a sua situação social estimula o internamento, mobilizado por um crime primeiro que cristalizou a sua violência. Erasmo, nesta última internação, parece ter incorporado o discurso da estratégia, e a periculosidade e inimputabilidade parecem se cristalizar em sua pessoa com uma doença que ameaça e que encontra no HCT o seu lugar:

... Eu tava doente, eu estava muito doente, uma pessoa no meu estado doente já é uma ameaça, tanto para minha pessoa quanto para outra pessoa. Eu acho uma ameaça eu, descontrolado e sem medicação... posso descompensar, então tenho que me prevenir, para segurança minha e segurança da sociedade também... Eu acho que eu estou consciente que eu precisava de um tratamento... eu tô consciente também que e u preciso de medicação para continuar lúcido, ser uma pessoa normal, no meio de uma sociedade normal, sem causar transtorno, um comportamento 


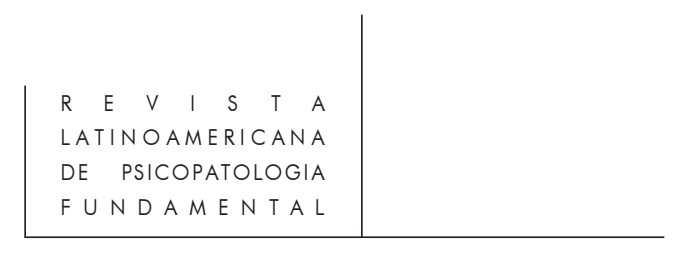

adverso que venha machucar alguém, agredir alguma pessoa por causa de meu comportamento esquizofrênico... eu tenho, vamos dizer assim, um gênio doente... se eu tiver fora de controle medicamentoso, eu posso ser realmente agressivo, fantasiar as vozes da doença e a partir daí fazer uma agressão, que eu já tenho provas concretas que eu posso ser capaz de fazer uma agressão quando eu tô fora de medicação... (Entrevista com Erasmo, grifos meus)

Erasmo agora é a ameaça que sua doença representa. No entanto, não podemos deixar de considerar o seu percurso até o momento atual, quando este discurso é produzido. A doença, e mais ainda, a doença perigosa, parecem ter se constituído como uma possibilidade: diante de inúmeras entradas e saídas e de uma série de impossibilidades impostas à sua vida, o retorno ao manicômio apareceu como uma saída. Ele volta por não ter casa, comida, trabalho, família, por não poder mais voltar à sua cidade: o HCT apareceu como um porto final, em um percurso que, provavelmente, ainda não acabou; o futuro ficará em aberto. Desta forma, pensamos que este discurso da periculosidade marca um produto desta estratégia: Erasmo é ameaça, sua doença é violenta, ele adaptou-se à estratégia que o envolveu (Foucault, 1971; 1991).

Como dois elementos que se somam para encerrarmos este "percurso jurídico", tomaremos o Laudo de Cessação de Periculosidade, em outubro do mesmo ano. Na conclusão do Laudo de Cessação, afirmam os peritos:

Erasmo agora está convivendo melhor com esta situação e desta vez faz planos mais reais. Sobreviver sem ajuda da família, com sua aposentadoria, e durante o período que está aqui vem economizando alguma quantia para alugar um cômodo e "morar" fora do Hospital. "Morar fora do Hospital" porque ele na realidade está morando neste nosocômio porque já não exibe sintomatologia psiquiátrica para mantê-lo internado e seu retorno se deu por problemas sociais. Concluímos de modo favorável à desinternação do paciente.

É no Parecer Social, entretanto, que tomamos conhecimento de seus "planos mais reais":

... pretende alugar um quartinho e trabalhar como autônomo vendendo cafezinho, picolé ou cachorro quente, de forma a aumentar seus rendimentos mensais. É consciente da situação que o cerca e dos obstáculos que irá enfrentar lá fora. Ressaltamos ser o mesmo aposentado por invalidez e receber um salário mínimo, dispondo desta forma de uma fonte de renda para manter o seu próprio sustento, além, também, de poder contar com o amparo de familiares.

São estes os últimos documentos presentes em seu "prontuário jurídico", e neles podemos perceber como foi se conformando "o que vai ser": Erasmo, um doente mental que cometeu um crime e que, a partir desse ato entrou na estratégia da periculosidade. A psiquiatria e o direito criminal, nesta união possibilitada por 


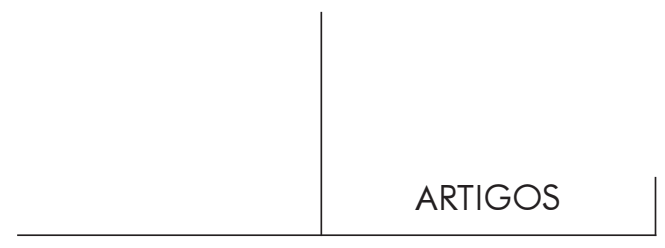

uma doença que se faz delito, marcaram este percurso. Este Erasmo "selvagem", aquele que "apresenta uma fúria incontida", agora pede para ser internado no HCT e lá, "mora" com certos privilégios: como um "louco-lúcido", ajuda os funcionários em alguns serviços, chama os pacientes para tomarem medicação, tem passagem livre para a parte interna da instituição.

Nesta complexa rede que se instaura, uma série de conceitos se mostram significativos em uma multiplicidade de sentidos. É através deles, e de tudo que neles se acha implicado, que Erasmo morre socialmente. A Medida de Segurança, que olha para o futuro, que não é punição, que não tem caráter aflitivo, que não guarda relação com o crime, mas sim com a periculosidade, é a tática - através dela a estratégia entra em ação; a inimputabilidade, que retira do sujeito o seu ato e o toma como fruto de uma doença; a irresponsabilidade que "...retira as conseqüências que a lei considera como produzidas pelo ato..." (Escorel, s/d, p. 49), ou seja, a punição; a periculosidade que é risco (Barbier, 1990, pp. 1327). No discurso jurídico, o louco-criminoso não é culpado, não é punido... mas também não é julgado como um “criminoso comum”, a ele, torna-se impossível a defesa: nunca saberemos se o crime de Erasmo foi um acidente.

Esta é a forma de reconhecer este Estranho: através de uma estratégia que em discurso absolve, trata, previne, mas que na prática multiplica-se através do tempo com uma série de artifícios possibilitados pela flexibilidade que é a sua marca. Uma internação que pode ser indeterminada, uma liberdade condicional, uma periculosidade que é futuro e legalmente prevista. Não podemos deixar, neste momento de nos lembrar das palavras de Althusser: "o futuro dura muito tempo" (1992). É neste tempo que a Medida de Segurança atua. Estranha absolvição esta a da loucura... ela visa, como nos disse Hungria, a prevenção, a "neutralização profilática” (1978). Como possibilitadora da estratégia, a psiquiatria reconhece a doença, a qual estabelece a identificação do louco criminoso como perigoso, inimputável, irresponsável e, em decorrência dessa doença reconhecida, a estratégia é posta em ato. Todos estes elementos estão presentes no nosso Código Penal, são lei.

Vemos então que a ambigüidade do HCT, instituição que tem por fim custodiar e tratar, se acha presente de uma forma geral na estratégia que ela representa. A Medida de Segurança, a inimputabilidade, a irresponsabilidade, a absolvição da loucura-criminosa são ambíguas, na prática parecem aflitivas, e o HCT mostra-se como uma instituição marcada pela dupla tratamento e punição. Para concluir, vejamos como Erasmo põe em discurso o ato fundante, 14 anos após a sua primeira internação, depois de muitas entradas e saídas no HCT:

... a parte de violência, né, que ocorreu em minha vida durante essa trajetória que me trouxe pr'aqui. Teve um dia que eu disse: "Pôxa! Eu aqui humilhado, por causa de dinheiro..". Mas eu já tava doente, já era uma psicose, uma mania... Aí chegou de noite e eu comecei, deu uma loucura em mim tão grande que eu comecei a discursar 


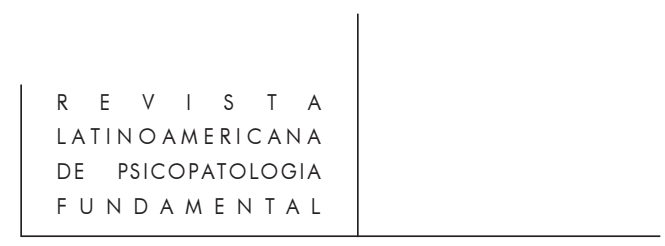

na rua, falando um bocado de coisa... eu mesmo não entendia uma palavra do que eu tava dizendo... eu não entendi uma frase do que eu disse. Quando eu entrei em casa, minha yyy saiu do quarto, ficou na porta da rua. Minha xxx encostou na parede e meu www saiu de dentro do quarto com uma trave... eu tomei, minha xxx se jogou assim contra eu e ele e eu empurrei a velha para frente. Na saída agredi minha yyy, quebrei o pau e arranquei o fio de telefone para eles não chamarem a polícia. Eu tava com intenção de entrar, pegar um cobertor e dormir na rua: outro sinal de desequilíbrio...Como é que eu posso me sentir culpado, se eu não tinha premeditado, se eu não tinha intenção de matar, a intenção de agredir ninguém. Eu entrei para pegar meu cobertor porque eu cismei de dormir no passeio, dormir no sereno, coisa de maluco... (Entrevista com Erasmo, grifos meus)

Esta fala de Erasmo se mostra interessante, uma vez que permite que sejam identificados os elementos desta estratégia incorporados ao seu discurso: depois de 14 anos de história, ele já é parte da rede que o engloba (Foucault, 1971; 1990). Erasmo, que negava a sua doença por considerá-la incapacitante, que queria ser julgado e provar o acidente, agora introduz seu crime no registro da loucura, uma loucura que é violenta. Desta forma, podemos perceber a incorporação da periculosidade e da inimputabilidade, elementos característicos da estratégia da periculosidade. Erasmo dá os sinais da doença que motivaram o seu ato: tinha uma psicose, uma mania, falava sozinho e coisas que nem ele entendia, queria dormir na rua; a culpa ele diz ausente pelo crime sem intenção, pelo ato no impulso, por ter sido "coisa de maluco". Seu ato não lhe pertence e ele não pede mais para ser julgado: produz-se em Erasmo um discurso que os aceita, doença e delito, em uma periculosidade que ele representa.

\section{Bibliografia}

Althusser, Louis. O futuro dura muito tempo. Trad. de Rosa Freire d'Aguiar. São Paulo, Companhia das Letras, 1992.

Amarante, Paulo. "Asilos, alienados e alienistas: uma pequena história da psiquiatria no Brasil", in Psiquiatria social e reforma psiquiátrica. Rio de Janeiro, Fiocruz, 1994, pp. 73-84.

BARBIER, Dominique. "Alice au pays des merveilles ou les difficultés de l'expert face à la dangerosité”, in La Dangerosité - approche pénale et psychiatrique. Toulouse, Privat, 1990, pp. 13-27.

Bercherie, Paul. Los fundamentos de la clínica: história y estrutura del saber psiquiátrico. Trad. de Carlos A. de Santos. Buenos Aires, Manantial, 1986.

Birman, Joel. A psiquiatria como discurso da moralidade. Rio de Janeiro, Graal, 1978.

CArrara, Sergio Luis. "Crime e loucura: o aparecimento do Manicômio Judiciário na passagem do século". Dissertação de Mestrado. Universidade Federal do Rio de Janeiro, Museu Nacional, 1987. 


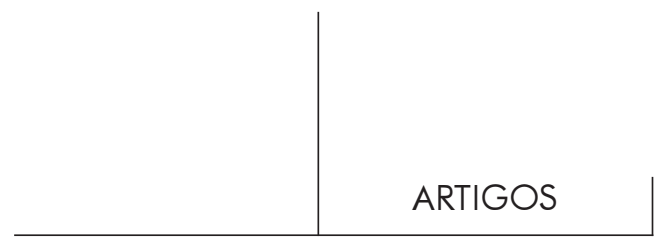

"Casos e acasos: o crime de um certo Custódio e o surgimento do Manicômio Judiciário no Brasil”. Cadernos do IMS, Rio de Janeiro, Instituto de Medicina Social/ UERJ, 1989, pp. 73-107.

Castel, Robert. A ordem psiquiátrica: a idade de ouro do alienismo. Trad. de Maria Tereza da Costa Albuquerque. Rio de Janeiro, Graal, 1978.

"Os médicos e os juízes", in Foucault, Michel. Eu, Pierre Rivière, que degolei minha mãe, minha irmã e meu irmão... Um caso de parricídio do século XIX. Trad. Denise Lezan de Almeida. Rio de Janeiro, Graal, 1991, pp. 259-275.

Cohen, Claudio. "Medida de Segurança", in Cohen, C.; Carvalho Ferraz, F. e Segre, M. (orgs.). Saúde mental, crime e justiça. São Paulo, EDUSP, 1996, pp. 77-86.

Costa e Silva, José da. Código Penal dos Estados Unidos do Brasil. São Paulo, Companhia Editora Nacional, 1930.

Dantas JR., Alírio Torres. "O Manicômio Judiciário e o conflito de identidade da psiquiatria”. Revista $A B P-A P A L$, vol. 9, nํㅜ 03, pp. 103-106, 1987.

Delmanto, Celso. Código Penal comentado. São Paulo, Renovar, 1991.

Escorel, Manoel Clementino de Oliveira. Código Penal Brasileiro. São Paulo, Duprat e comp., vol. I, 1905.

Ewald, François. Foucault, a norma e o direito. Trad. de António Fernando Cascais, Lisboa, Vega, 1993.

Fontana, Alexandre. "As intermitências da razão", in Foucault, Michel. Eu, Pierre Rivière, que degolei minha mãe, minha irmã e meu irmão... um caso de parricídio do século XIX. Op. cit., pp. 277-294.

Foucault, Michel. História da loucura. Trad. de José Teixeira Coelho Neto. São Paulo, Perspectiva, 1995

"A verdade e as formas jurídicas", ciclo de conferências realizado no Depto. de Letras e Artes da PUC-RJ. Ed. dirigida por Afonso Romano de Sant'Anna. Tradução de Roberto Dias Machado e Eduardo Morais. PUC-RJ, divisão de intercâmbios e edições, 1973.

Vigiar e punir. História da violência nas prisões. Trad. de Lígia M. Pondé Vassalo. Petrópolis, Vozes, 1991.

Microfísica do poder. Tradução de Roberto Machado. Rio de Janeiro, Graal, 1995. Eu, Pierre Rivière, que degolei minha mãe, minha irmã e meu irmão,...Um caso de parricídio do século XIX. Op. cit.

"La evolución de la noción de 'individuo peligroso' en la psiquiatría legal", in La vida de los hombres infames - ensayos sobre desviación y dominación. Trad. de Julia Varela e Fernando Elvares Uria. Madrid, La Piqueta, 1990, pp. 231-264.

L'ordre du discours. Paris, Gallimard, 1971.

A história da sexualidade I - A vontade de saber. Trad. de Maria Thereza da Costa Albuquerque e J. A Guilhon Albuquerque. Rio de Janeiro, Graal, 1988.

O Sujeito e o Poder, in Rabinow, Paul e Dreyfus, Hubert. Michel Foucault. Uma trajetória filosófica - para além do estruturalismo e da hermenêutica.Trad. de Vera 


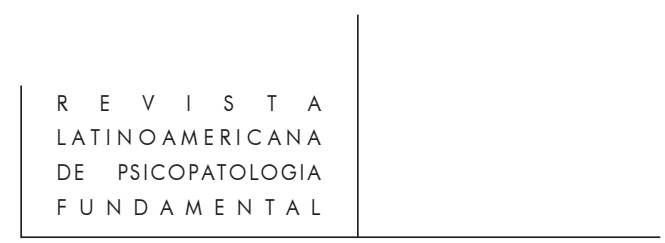

Porto Carrero. Rio de Janeiro, Forense Universitária, 1995, 231-249.

Freud, Sigmund. “O estranho”. E.S.B., vol. XVIII. Rio de Janeiro, Imago, 1987, pp. 273-318.

Harris, Ruth. Assassinato e loucura: medicina, leis e sociedade no fin de siècle. Trad. de Talita M. Rodrigues. Rio de Janeiro, Rocco, 1993.

Hungria, Nelson e Fragoso, Heleno. Comentários ao Código Penal. Rio de Janeiro, Forense, 1978.

Jesus, Damásio E. de. Direito Penal. São Paulo, Saraiva, 1988.

LANTERI-LAURA, Georges. "La dangerosité em psychiatrie, perspectives historiques", in Dominique Barbier (org.). La dangerosité - approche pénale et psychiatrique. Toulouse, Privat, 1990, pp. 39-50.

Machado, Roberto et al. Danação da Norma: medicina social e constituição da psiquiatria no Brasil. Rio de Janeiro, Graal, 1978.

Moura, Luiz Antonio. "Imputabilidade, semi-imputabilidade e inimputabilidade", in Cohen, Claudio, Ferraz, Flavio Carvalho e Segre, Marco (orgs.). Saúde Mental, Crime e Justiça. Op. cit., pp. 85-104.

Noronha, E. Magalhães. Direito Penal. São Paulo, Saraiva, 1990, v. 1.

Oliveira e Silva. Inovações do Novo Código Penal. Rio de Janeiro, Alba, 1942.

Pessoti, Isaías. A loucura e as épocas. Rio de Janeiro, Editora 34, 1994.

Rabinow, Paul. \& Dreyfus, Hubert. Michel Foucault - uma trajetória filosófica para além do estruturalismo e da hermenêutica. Trad. de Vera Porto Carrero. Rio de Janeiro, Forense Universitária, 1995.

SÁ, Evelin Nacked de Castro. "O Manicômio Judiciário: saúde ou Justiça?” Rev. de saúde Publ. S. Paulo, 19: 389-400, 1985.

Soares, Oscar de Macêdo. Código Penal da República dos Estados Unidos do Brasil. Rio de Janeiro, Livraria Garnier, s/d.

\section{Resumos}

En ese texto buscaré discutir los mecanismos de control social que se han desarrollado alrededor de los enfermos mentales criminales como saberes y prácticas institucionales, los cuales se estructuram segundo las estrategias medico-psiquiatricas y juridico-penales. Por medio de la reconstrucción del caso de un paciente interno en un Hospital de Custodia y Tratamiento, intentaré demostrar como se articula alrededor de la noción de peligrosidad una red que involucra saberes, prácticas, instituciones y leyes, los cuales actuan en la formación de una nueva subjetividad: el extraño sujeto de la peligrosidad.

Palabras-llave: Controle social, locura criminal, hospitalización, salud comunitaria. 


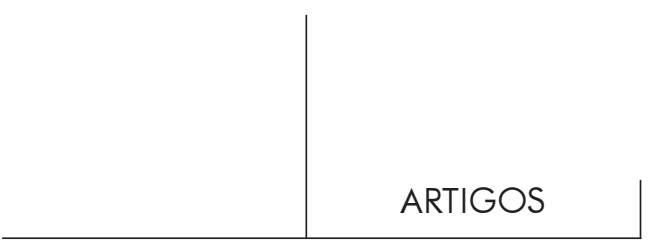

Dans cette article nous voulons étudier les mécanismes de contrôle social qui se sont développés autour des malades mentales criminels sous la forme de savoirs et de practiques institués. Ces-ci sont organisés d'aprés les estratégies medicopsychiatriques et juridico-penale. Moyennant la réconstruction du cas d'un patient interné dans un Hospital de Custódia e Tratamento, nous essayons de démontrer comment tout un réseau est articulé autour de la notion de dangerosité, réseau qui comprend des savoirs, des practiques, des institutions et des lois. Ainsi nous pourrons éxaminer la formation d'une nouvelle subjectivité: l'insolite sujet de la dangerosité.

Mots-clef: Contrôle social, démence criminel, hospitalisation, santé communautaire.

This paper aims to discuss the mechanisms of social control which were developed concerning criminal mentally ills in the form of institutionalised knowledges and practices. These are organised accordingly to psychiatric and legal (penal) strategies. Through the history of a patient of a Hospital de Custódia e Tratamento we try to demonstrate how a web - constituted of knowledges, practices, institutions and laws - is constructed on the same notion of dangerousness. So we can examine the constitution of a new subjectivity: the uncanny dangerousness subject.

Key words: Social control, criminal madness, hospitalization, community health. 